\title{
A sensorineural progressive autosomal recessive form of isolated deafness, DFNB13, maps to chromosome 7q34-q36
}

\author{
M irna M ustapha ${ }^{1}$, Sébastien Chardenoux ${ }^{2}$, A lexandre N ieder $^{1}$, Nabiha Salem ${ }^{1}$, J ean \\ Weissenbach ${ }^{3}$, Elie E I-Zir ${ }^{4}$, Jacques L oiselet ${ }^{1}$ and Christine Petit ${ }^{2}$ \\ ${ }^{1} L$ aboratoire de Biochimie, Faculté de $M$ édecine, U niversité Saint-J oseph, B eyrouth, $L$ ebanon \\ 'U nité de Génétique des D éficits Sensoriels, CNRS URA 1968, Institut Pasteur, Paris, France \\ ${ }^{3} \mathrm{C}$ entre $\mathrm{N}$ ational de Séquençage, E vry, France \\ ${ }^{4}$ Clinique d'A udiologie, $\mathrm{H}$ ôpital du Sacré-C oeur, B aabda, B razilia, L ebanon
}

\begin{abstract}
Deafness is the most frequent sensorineural defect in children. The vast majority of the prelingual forms of isolated deafness are highly genetically heterogeneous with an autosomal recessive mode of inheritance. Using linkage analysis, we have mapped the gene responsible for a severe progressive sensorineural hearing loss, DFNB13, segregating in a large consanguineous family living in an isolated region in northern Lebanon. A maximum lod score of 4.5 was detected for markers D7S661-D7S498. Recombination events and homozygosity mapping by descent define a $17 \mathrm{cM}$ gene interval in the chromosome region 7q34-q36, between the markers D7S2468/D7S2505, on the proximal side, and D7S2439, on the distal side.
\end{abstract}

Keywords: non-syndromic sensorineural deafness; homozygosity mapping; gene localisation

\section{Introduction}

The congenital and prelingual inherited forms of isolated deafness are, in $85-90 \%$ of the cases, transmitted in an autosomal recessive mode, ( ${ }^{1}$ for a review). These forms most frequently cause severe or profound hearing loss, which impedes language acquisition. They are genetically monogenic heterogeneous diseases. ${ }^{2}$ So far, no clinical signs allow distinction between the defects due to different genes. D ue to these characteristics, coupled with the tendency of deaf people to

Correspondence: D r Christine Petit, U nité de G énétique des D éficits Sensoriels, CNR S U R A 1968, Institut Pasteur, 25 rue du Dr R oux, 75724 Paris cedex 15, France. Tel: 331456888 90; Fax: 331456769 78; E mail: cpetit@pasteur.fr

Received 15 September 1997; revised 12 November 1997; accepted 27 November 1997 intermarry, at least in developed countries, mapping of the corresponding loci (DFNB loci) had long been considered impossible. These difficulties have been circumvented by genetic analysis using three different approaches, $\left({ }^{1}\right.$ for a review). O ne of these approaches, the first described in, ${ }^{1}$ is based on the study of large affected consanguineous families living in isolated regions for several generations. In such families, the probability of having more than one deafness gene segregating is minimised. $U$ sing this approach, we were able to localise the first two genes involved in autosomal recessive deafness, DFNB $1^{3}$ and DFNB2, ${ }^{4}$ segregating in large families living in northern and southern Tunisia, respectively. Once linkage to a particular chromosomal region has been detected by linkage analysis, the localisation interval can be refined by the 
characterisation of homozygous regions present in affected individuals. To date, 13 loci underlying autosomal recessive forms of deafness have been reported, DFNB1-12 (see ${ }^{1}$ ) and DFNB16 ${ }^{5}$ (with four of these probably representing only two different loci, detailed below), mainly by the study of large consanguineous families living in geographic isolates. We have concentrated our search to identify genes responsible for autosomal recessive deafness, by analysing affected families living in isolated villages, on different countries around the M editerranean Sea, particularly L ebanon. ${ }^{6,7}$ In order to identify the target or defective DFNB Ioci present in the Lebanese population, we have collected blood samples from large affected families from different communities. We report here on the identification of a new locus, DFNB 13, in a family belonging to the Christian $\mathrm{M}$ aronite faith.

\section{Results}

\section{Clinical Description}

In family J, a marriage between two first cousins, individuals 40 and 41 , resulted in 16 children, 13 of whom are alive (Figure 1). Five of them have been recognised as affected with deafness in the prelingual period, although audiometric tests were only performed during this genetic study. The age of the patients ranged from 8 to 26 years. Pure tone audiometry showed that the youngest individuals were less affected than the older ones. $A$ ir and bone conduction revealed a bilateral hearing loss of 50 to $70 \mathrm{~dB} \mathrm{HL}$ at all frequencies for the younger patients, and 80 to 100 $\mathrm{dBH} \mathrm{L}$ for the older patients. A udiologic performances of both parents were normal. No other symptom was associated with the deafness, therefore indicating that a progressive, severe form of isolated sensorineural deafness segregates in this family.

\section{Linkage Mapping}

In the first instance, we performed an exclusion analysis with the polymorphic microsatellite markers corresponding to nine previously identified DFNB loci, DFNB $1,{ }^{3}$ DFNB $2,{ }^{4}$ DFNB $3{ }^{8}$ DFNB $5,{ }^{9}$ DFNB $6,{ }^{10}$ DFNB $7 / 11,{ }^{11,12}$ DFNB 8/10, ${ }^{13,14}$ DFNB $9,{ }^{6}$ D FNB $12 .{ }^{7}$ We excluded the DFNB 4 locus ${ }^{15}$ from this analysis, as there is increasing evidence that this locus does not actually underly an isolated form of deafness, but is rather a syndromic form, Pendred syndrome; ${ }^{16,17}$ small thyroid goitres have been detected in the older individuals of the previously DFNB4-designated families. Since no linkage was observed between these nine loci and segregation of the deafness in family J, we undertook an extensive analysis using the Généthon collection of polymorphic markers spaced about $15-20 \mathrm{cM}$ apart. ${ }^{18} \mathrm{~A}$ significant lod score of 4.5 was detected at locus D 7S661, on chromosome 7; the five affected children were all homozygous for this marker.

To define further the position of this new locus, D FNB 13, the flanking markers were tested (see Figure 2). A nalysis of the recombinants in generation IV showed that the affected individual 42 is heterozygous for the most distal locus D7S2439 and that the nonaffected individual 49 is homozygous for the three most centromeric loci, D 7S684, D 7S2505 and D 7S2468 (Figure 1). Thereby, the DFNB13 locus was mapped to a $17 \mathrm{cM}$ interval of chromosome 7q34-q36, flanked by D 7S2505/D 7S2468 (loci not yet ordered) proximally and D 752439 distally.

\section{Discussion}

U sing linkage analysis, we have identified a novel locus, DFNB 13, underlying an isolated autosomal recessive, progressive form of sensorineural deafness segregating in a large consanguineous family from L ebanon.

A mong the 13 DFNB loci identified so far, for only two of them has the corresponding gene been cloned. $M$ utations in $\mathrm{Cx} 26$, the gene encoding the gap junction protein connexin 26 , have been shown to be responsible for D FNB 1 and D FNA $3^{19-22}$ and mutations in MYO 7A, the gene encoding the unconventional myosin VIIA, for DFNB2. ${ }^{23,24}$ These two studies also proved correct the hypotheses, based on linkage results, that (i) the same gene can be responsible for both a recessive (DFNB 1) and a dominant (DFNA 3) form of deafness ${ }^{25}$ and that (ii) the same gene can be responsible for an isolated (DFNB 2) and a syndromic (U SH 1B) form of deafness. ${ }^{4,26}$ Since the autosomal dominant form of deafness, DFNA 11, has been assigned to the same chromosomal region as D FN B 2 and U SH 1B, ${ }^{27}$ M Y O 7A is also likely to underly this dominant form of isolated deafness. Based on these considerations, we searched for a dominant form of isolated deafness or a syndromic form of deafness reportedly assigned to the same chromosomal region as DFNB13. So far, however, neither has been mapped to this chromosomal interval. A locus for the R omano-Ward syndrome, the autosomal dominant form of the long QT syndrome has been assigned to $7 q 35-q 36 .{ }^{28}$ The only gene identified as responsible for Jervell and Lange-Nielsen syndrome 


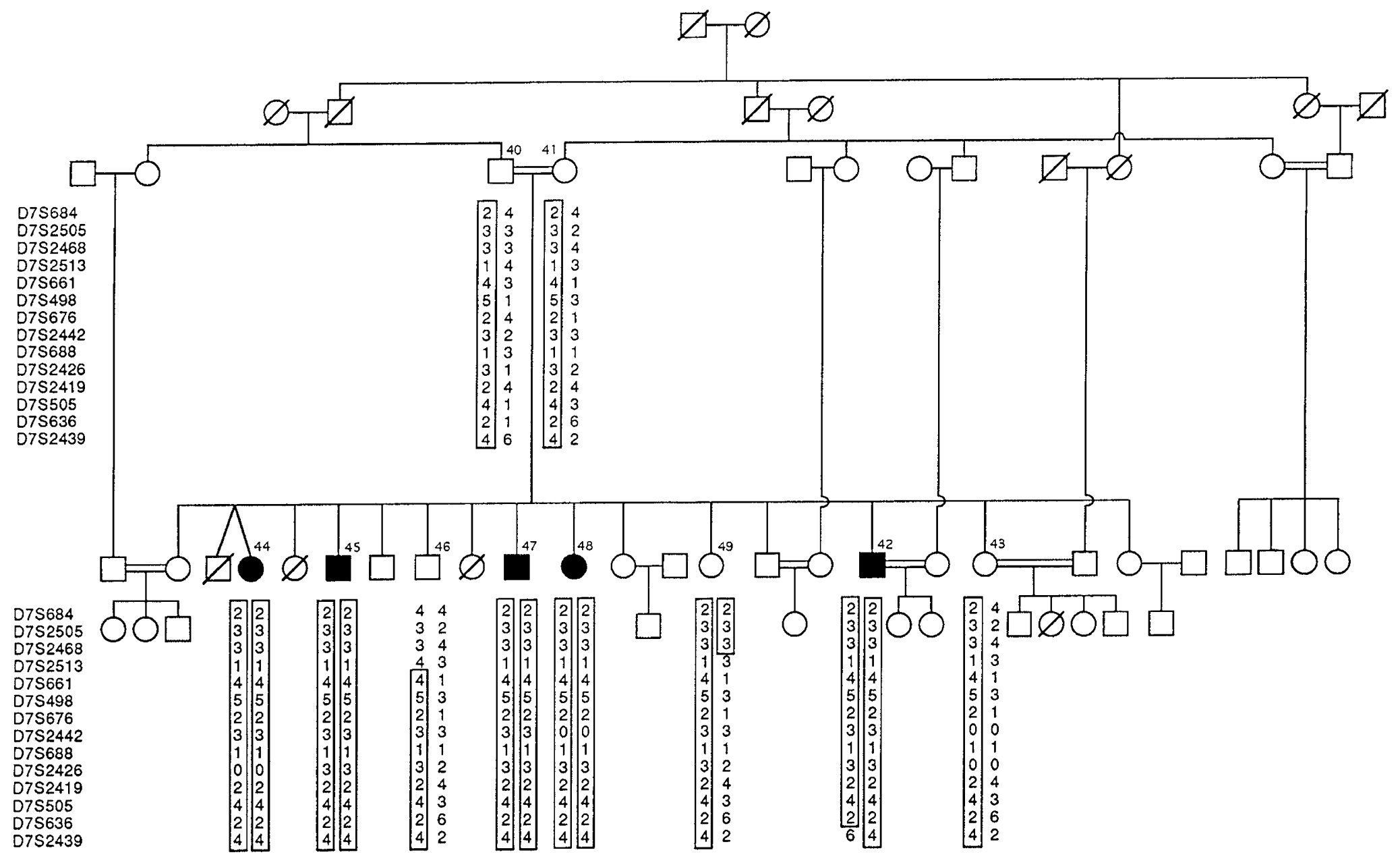

Figure 1 Segregation analysis of family J affected by a sensorineural, isolated, autosomal recessive form of deafness using AFM polymorphic markers in the 7q34-q36 region. ${ }^{18}$ Dark symbols represent deaf individuals. The core haplotype associated with DFNB13 is boxed 
(located on 11p15.5), an autosomal recessive disease characterised by a congenital deafness associated with QT prolongation, involves the same gene as one form of Romano-Ward syndrome. ${ }^{29}$ Therefore, cardiologic examinations were conducted in family $J$, the results of which have excluded the possibility that Jervell and $L$ ange- $\mathrm{N}$ ielsen syndrome segregates in this family.

A mong the numerous deaf mouse mutants, several have already been proven to involve genes orthologous to those implicated in human deafness (for a review, see $^{1}$ ), therefore facilitating the cloning of the latter. We searched for a deaf mouse mutant assigned to the murine chromosomal region orthologous to human 7q34-q36, ie a region of mouse chromosomes 5 (10-16 cM from the centromere) and 6 (17-20 cM). None has been reported.

Therefore, considering the large size of the chromosomal interval presently defined for DFNB13, only a candidate gene approach can be attempted for the

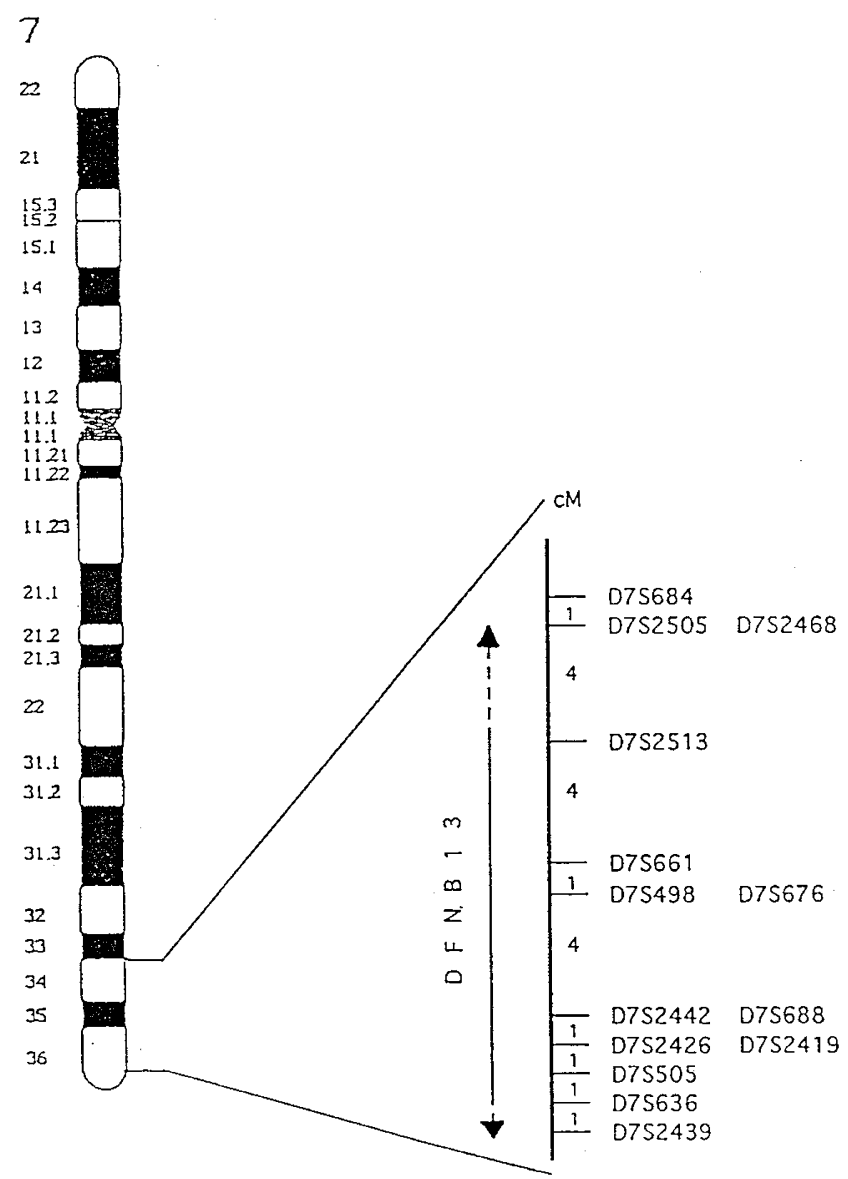

Figure 2 Schematic representation of chromosome 7 showing the localisation interval of the isolated recessive deafness D F N B 13. The indicated loci have been revealed with markers from the $\mathrm{G}$ énéthon collection ${ }^{18}$ cloning of this gene. A number of ESTs (Expressed Sequence Tags), as well as fully sequenced CDNA S, have been mapped to this chromosomal interval. A mong them, priority should be given to the gene encoding the 'single-stranded DNA-binding protein mitochondrial precursor' (SSBP) ${ }^{30}$ candidate gene, since mitochondrial metabolism is known to be crucial for auditory function. ${ }^{31-34}$ In addition, in order to refine the localisation interval of DFNB 13, linkage analysis of deaf individuals from additional families living in the same geographical area and belonging to the same community will be performed.

\section{Materials and Methods}

\section{Auditory Tests}

Informed consent was obtained from adult subjects and from parents of under-aged patients. Pure tone audiometry with aerial and bone conduction at 250, 500, 1000, 2000, 4000 and $8000 \mathrm{~Hz}$ were systematically performed (with Beltone 2000 clinical audiometer), as well as otoscopic examinations, for each individual over 5 years of age.

\section{Genotyping}

DNA was prepared from $5-10 \mathrm{ml}$ of blood by standard phenol-chloroform extractions. Fluorescent microsatellite markers ${ }^{18}$ were amplified using the polymerase chain reaction $(\mathrm{PCR})^{35}$ and resultant products analysed following electrophoresis on a $6 \%$ polyacrylamide gel.

\section{Linkage Analysis}

Lod scores were calculated using the MAPMAKER/ HOMOZ program ${ }^{36}$ (version 0.9), an algorithm for rapid multipoint analysis. The disease was assumed to be inherited in a recessive mode and fully penetrant. The gene frequency was set at $10^{-5}$ and variation of this frequency between $10^{-3}$ and $10^{-5}$ resulted in negligible variations of the multipoint lod scores. Meiotic recombination frequencies were assumed to be equal for males and females. The allele frequencies of the polymorphic markers were assumed to be equal.

\section{Acknowledgements}

We are grateful to the patients and their families who participated in this work. We thank $S$ Elias for careful cardiological examination of family $\mathrm{J}$, and J-P $\mathrm{H}$ ardelin, $\mathrm{V}$ $K$ alatzis and J L evilliers for critical reading of the manuscript. This work was supported by the A and M Suchert foundation, the A ssociation Entendre, and EEC (grant BMH 4CT96-1324). 


\section{References}

1 Petit C: G enes responsible for human hereditary deafness: symphony of a thousand. Nat G enet 1996; 14: 385-391.

2 Morton NE: Genetic epidemiology of hearing impairment: In: G enetics of H earing I mpairment. The N ew York A cad. Sci. 1991, vol 630; pp 16-31.

3 Guilford P, Ben A rab S, Blanchard S et al: A nonsyndromic form of neurosensory, recessive deafness maps to the pericentromeric region of chromosome $13 q$. Nat G enet 1994; 6: 24-28.

4 Guilford $\mathrm{P}$, A yadi $\mathrm{H}$, Blanchard $\mathrm{S}$ et al: A human gene responsible for neurosensory, non-syndromic recessive deafness is a candidate homologue of the mouse sh-1 gene. $\mathrm{H}$ um M ol G enet 1994; 3: 989-993.

5 Campbell DA, M CH ale D P, B rown KA et al: $A$ new locus for non-syndromal autosomal recessive sensorineural hearing loss (DFNB16) maps to 15q21-q22. J M ed Genet 1997; 34: 1015-1017.

6 Chaib $\mathrm{H}$, Place $\mathrm{C}$, Salem $\mathrm{N}$ et al: A gene responsible for a sensorineural nonsyndromic recessive deafness maps to chromosome 2p22-23. H um Mol G enet 1996; 5: 155-158.

7 Chaib H, Place C, Salem N et al: M apping of D F N B 12, a gene for a non-syndromal autosomal recessive deafness, to chromosome 10q21-22. H um $\mathrm{M}$ ol Genet 1996; 5: 1061-1064.

8 Friedman TB, Liang $Y$, Weber $\mathrm{JL}$ et al: A gene for congenital, recessive deafness DFNB3 maps to the pericentromeric region of chromosome 17 . N at $\mathrm{G}$ enet 1995; 9: 86-91.

9 Fukushima K, Ramesh A, Srisailapathy CRS et al: Consanguineous nuclear families used to identify a new locus for recessive non-syndromic hearing loss on 14q. H um M ol G enet 1995; 4: 1643-1648.

10 Fukushima K, Ramesh A, Srisailapathy CRS et al: A n autosomal recessive non-syndromic form of sensorineural hearing loss maps to 3p-DFNB6. Genome Res 1995; 5: 305-308.

11 Jain PK, Fukushima K, Deshmukh D et al: A human recessive neurosensory nonsyndromic hearing impairment locus is a potential homologue of the murine deafness (dn) locus. H um Mol G enet 1995; 4: 2391-2394.

12 Scott DA , Carmi R, Elbedour K, Y osefsberg S, Stone E M, Sheffield VC: A $n$ autosomal recessive nonsyndromichearing-loss locus identified by DNA pooling using two inbred Bedouin kindreds. A m J Hum Genet 1996; 59: 385-391.

13 Veske A, Oehlmann R, Younus $F$ et al: A utosomal recessive non-syndromic deafness locus (DFNB8) maps on chromosome 21q22 in a large consanguineous kindred from Pakistan. H um M ol G enet 1996; 5: 165-168.

14 B onné-Tamir B, D eStefano A L, B riggs CE et al: L inkage of congenital recessive deafness (gene DFNB10) to chromosome 21q22.3. Am 」 Hum Genet 1996; 58: 1254-1259.

15 Baldwin CT, Weiss S, Farrer $L A$ et al: Linkage of congenital, recessive deafness (DFNB 4) to chromosome $7 q 31$ and evidence for genetic heterogeneity in the Middle Eastern Druze population. Hum Mol Genet 1995; 4: 1637-1642.
16 Coyle B, Coffey R, A rmour JA L et al: Pendred syndrome (goitre and sensorineural hearing loss) maps to chromosome 7 in the region containing the nonsyndromic deafness gene DFNB 4. Nat G enet 1996; 12: 421-423.

17 Sheffield V C, K raiem Z, B eck J C et al: Pendred syndrome maps to chromosome 7q21-34 and is caused by an intrinsic defect in thyroid iodine organification. $\mathrm{N}$ at $\mathrm{G}$ enet 1996; 12: 424- 426.

18 Dib C, Fauré S, Fizames $C$ et al: A comprehensive genetic map on the human genome based on 5,264 microsatellites. Nature 1996; 380: 152-154.

19 Kelsell DP, Dunlop J, Stevens HP et al: Connexin 26 mutations in hereditary non-syndromic sensorineural deafness. N ature 1997; 387: 80-83.

20 Zelante L, Gasparini P, E stivill $X$ et al: Connexin 26 mutations associated with the most common form of nonsyndromic neurosensory autosomal recessive deafness (DFNB 1) in Mediterraneans. Hum Mol Genet 1997; 6: 1605-1609.

21 Carrasquillo M M, Zlotogora J, Barges S, Chakravarti A : Two different connexin 26 mutations in an inbred kindred segregating non-syndromic recessive deafness: implications for genetic studies in isolated populations. $\mathrm{H}$ um $\mathrm{M}$ ol Genet 1997; 6: 2163-2172.

22 Denoyelle F, Weil D, M aw MA et al: Prelingual deafness: high prevalence of a 30delG mutation in the connexin26 gene. $\mathrm{H}$ um M ol G enet 1997; 6: 2173-2177.

23 Liu X-Z, Walsh J, M buru P et al: M utations in the myosin VIIA gene cause non-syndromic recessive deafness. $\mathrm{N}$ at G enet 1997; 16: 188-190.

24 Weil $D, K$ üssel $P, B$ lanchard $S$ et al: The autosomal recessive isolated deafness, DFNB2, and the $U$ sher $1 B$ syndrome are allelic defects of the myosin-VIIA. Nat Genet 1997; 16: 191-193.

25 Chaib $H$, Lina-Granade $G, G$ uilford $P$ et al: $A$ gene responsible for a dominant form of neurosensory nonsyndromic deafness maps to the NSRD 1 recessive deafness gene interval. $\mathrm{H}$ um M ol G enet 1994; 3: 2219-2222.

26 Weil D, Blanchard S, Kaplan J et al: D efective myosin VIIA gene responsible for Usher syndrome type $1 B$. Nature 1995; 374: 60-61.

27 Tamagawa $Y, K$ itamura $K$, I shida $T$ et al: $A$ gene for a dominant form of non-syndromic sensorineural deafness (DFNA 11) maps within the region containing the DFNB2 recessive deafness gene. Hum Mol Genet 1996; 5: 849-852.

28 Jiang $C$, A tkinson D, Towbin JA et al: Two long QT syndrome loci map to chromosomes 3 and 7 with evidence for further heterogeneity. $\mathrm{N}$ at $\mathrm{G}$ enet 1994; 8: 141-147.

29 Neyroud N, Tesson F, D enjoy I et al: A novel mutation in the potassium channel gene K VL QT 1 causes the Jervell and $\mathrm{L}$ ange- $\mathrm{N}$ ielsen cardioauditory syndrome. $\mathrm{N}$ at $\mathrm{G}$ enet 1997; 15: 186-189.

30 Tiranti V, Rossi E, Ruiz-Carrillo A et al: Chromosomal localization of mitochondrial transcription factor $A$ (TCF6), single-stranded DNA-binding protein (SSBP), and endonuclease G (ENDOG), three human housekeeping genes involved in mitochondrial biogenesis. G enomics 1995; 25: 559-564. 
31 Prezant TR, A gapian JV, B ohlman MC et al: Mitochondrial ribosomal RNA mutation associated with both antibiotic-induced and non-syndromic deafness. $\mathrm{N}$ at $\mathrm{G}$ enet 1993; 4: 289-294.

32 Reid FM, Vernham GA, Jacobs HT: A novel mitochondrial point mutation in a maternal pedigree with sensorineural deafness. H um M utat 1994; 3: 243-247.

33 Fischel-G hodsian N, Prezant TR, Fournier P, Stewart IA, Maw $M$ : Mitochondrial mutation associated with non syndromic deafness. A m J Otolaryngol 1995; 16: 403-408.
34 Reid FM, Rovio A, Holt IJ, Jacobs HT: Molecular phenotype of a human lymphoblastoid cell-line homoplasmic for the np 7445 deafness-associated mitochondrial mutation. Hum Mol G enet 1997; 6: 443-449.

35 G yapay G, G inot F, N guyen S, Vignal A, Weissenbach J : $G$ enotyping procedures in linkage mapping. M ethods: $A$ companion to methods in enzymol 1996; 9: 91-97.

36 Kruglyak L, Daly MJ, Lander ES: Rapid multipoint linkage analysis of recessive traits in nuclear families, including homozygosity mapping. A m J H um G enet 1995; 56: 519-527. 